Article

\title{
Towards a Genuine Economic and Monetary Union-Comments on a Roadmap
}

Ansgar Belke

Department for Macroeconomics, University Duisburg-Essen, Universitätsstraße 12, 45117 Essen, Germany; E-Mail: ansgar.belke@uni-due.de; Tel.: +49 201183 2276; Fax: +49 2011834181

\section{How to Cite this Article}

Belke, A. (2013). Towards a Genuine Economic and Monetary Union-Comments on a Roadmap. Politics and Governance, 1(1), 48-65.

\section{Acknowledgement}

This Article was published by Librello, Politics and Governance's former publisher.

\section{About the Journal}

Politics and Governance is an innovative new offering to the world of online publishing in the Political Sciences. An internationally peer-reviewed open access journal, Politics and Governance publishes significant, cutting-edge and multidisciplinary research drawn from all areas of Political Science.

www.cogitatiopress.com/politicsandgovernance

\section{Editors-in-Chief}

Professor Andrej J. Zwitter, Faculty of Law, University of Groningen, The Netherlands

Professor Amelia Hadfield, Department of Psychology, Politics and Sociology, Canterbury Christ Church University, UK

\section{Managing Editor}

Mr. António Vieira, Politics and Governance, Cogitatio Press, Portugal 


\title{
Towards a Genuine Economic and Monetary Union- Comments on a Roadmap
}

\author{
Ansgar Belke \\ Department for Macroeconomics, University Duisburg-Essen, Universitätsstraße 12, 45117 Essen, Germany; \\ E-Mail: ansgar.belke@uni-due.de; Tel.: +49 201183 2276; Fax: +49 2011834181
}

Submitted: 6 February 2013 | In revised form: 20 March 2013 | Accepted: 1 May 2013 |

Published: 17 May 2013

\begin{abstract}
The Van Rompuy Report and also additional proposals made by the European Commission outlined steps for a 'genuine Economic and Monetary Union'. This article explains, assesses and comments on the proposals made. Moreover, it outlines what could be recommendations in order to achieve a 'genuine Economic and Monetary Union'. For this purpose, details of the Interim Report are systematically evaluated. We also deal with different governance visions emerging from the ongoing euro area crisis and starts from different views of the 'North and the South' of the euro area on this issue. This contribution argues that there is an alternative option to the notion of cooperative fiscal federalism involving fiscal union, bailouts and debt mutualisation: competition-based fiscal federalism accompanied by a properly defined banking union. In order to be a successful one, any deal will have to come up with a successful recipe of how to (re-)create trust between European citizens and their elected governments.
\end{abstract}

Keywords: banking union; debt mutualisation; EU governance; Euro budget; Eurozone; genuine Economic and Monetary Union; North-South divide; shock absorber

\section{Introduction}

The June 2012 European Council invited the President of the European Council together with the Presidents of the Eurogroup, the ECB and the European Commission to develop "a specific and time-bound road map for the achievement of a genuine Economic and Monetary Union" [1]. The European Parliament launched an own-initiative procedure on this report [2]. On this basis, the European Commission delivered its ahead of mid-December EU Summit paper on 28 November 2012 [3].

The Interim Report was presented on 12 October 2012 [4] and the final report was published on 5 December 2012. The Interim Report, concentrating on the euro area Member States, lays down several proposals for the implementation of a real Economic and Monetary Union. This work programme is to be analysed in this paper and considers four main Building Blocks: 
1. Integrated financial framework (single European banking supervision, common deposit insurance and resolution framework);

2. Integrated budgetary framework (stronger economic governance, fiscal capacity and a safe and liquid financial asset for the euro area);

3. Integrated economic policy framework (reforms of the EU surveillance framework, promoting structural reforms through arrangements of a contractual nature, and strengthening macroprudential policy); and

\section{Ensuring democratic legitimacy and accountability of decision making.}

\subsection{Building Block 1-Integrated Financial Framework}

This Building Block essentially refers to the fragmentation of Eurozone financial markets, which has already been identified by ECB President Mario Draghi, on several occasions, as the most significant problem, due to its credit tightening effects. Hence, there is the necessity for an integrated financial framework which should consist (i) of a single supervisory authority, (ii) of a common resolution framework implemented by a common resolution authority, and (iii) of national deposit guarantee schemes erected on common standards. According to the Interim Report, all Building Blocks are logically intertwined. For instance, any method of sharing banking sector risks (Building Block 1) must rely on effective fiscal discipline (Building Block 2) if moral hazard of sovereigns is to be avoided.

Notably, the establishment of a single supervisory mechanism (SSM) has been labelled a priority goal. Moreover, the single supervisory mechanism should be hosted by the ECB, following a proposal by the EU Commission, and clearly separate the ECB's monetary policy from supervisory duties. It has to balance rights and obligations for all participating Member States. Finally, the SSM has to operate consistently with Single Market principles and is to be held accountable to the European public, i.e. the European Parliament. Since the deliberations of the Interim Report concentrate on the euro area Member States, it does not say anything about an extension to non-euro EU Member States, notably the UK.

Concerning resolution, the Interim Report heavily draws upon the EU Commission's Recovery and Resolution Directive. The resolution authority is intended to move from the national to the common level as soon as the SSM is set in place. Transitorily, banks have the possibility to be recapitalised directly by the ESM if they comply with 'appropriate conditionality'.

Finally, the Interim Report does not explicitly mention, but seems to suggest a common deposit insurance mechanism to ensure a level playing field. Again the Report is silent about the integration of non-euro EU members. At least it supports the view that even harmonising national guarantee schemes according to legislative proposal have a pre-emptive role in stabilising the financial system. As a basic principle, they should be funded by the financial sector itself to a sufficient extent.

\subsection{Building Block 2-Integrated Budgetary Framework}

The starting point for this section is the high degree of interdependence among Member States. For instance, the recent crisis has again dramatically shown that national budget policies can have euro area-wide (and beyond) spillovers. As a consequence, the Interim Report calls for complementing the current budget surveillance and coordination framework with a more ex ante focused scheme, for instance the 'Two-pack'. In the same vein, the euro area is to end up in a 'fully-fledged integrated budgetary framework'. The latter is hoped to "ensure sound budgetary policies at both the national and the European levels and, thus, sustainable growth and macroeconomic stability". Interestingly, the report sees EMU endowed with 'unique features', which necessitates a specific approach to the centralisation of budgetary instruments and fiscal insurance mechanisms ([4], p. 4). In passing, it introduces a clear macro policy assignment: whereas monetary policy is responsible for coping with symmetric shocks, fiscal policy is responsible for asymmetric shocks which are understood as country-specific but not region-specific.

In terms of a stronger economic governance, the ex ante coordination of Member States' annual budgets and their surveillance under financial distress have-according to the Interim Report-to be strengthened. In the short run, the main focus is on finalising and implementing the 'Two-pack' to strengthen fiscal governance in the euro area, starting from the 'Sixpack' and the Treaty on Stability, Coordination and Governance, which are already in force.

By gradually developing what will be decided at the December European Council no more closely specified than new fiscal capacity with new fiscal functions for the EMU, the authors intend to deliver an additional valve to relieve asymmetric shocks, i.e. shocks to specific Member States. As a first explanation, the Interim Report refers to "low levels of cross-country labour mobility and structural impediments to price flexibility (which) make economic adjustment mechanisms less effective than in other monetary unions" as a 'unique feature' of the EMU. A second rationale is to facilitate structural reforms which are beneficial for competitiveness and growth-surely a concession to the 'Northern', in particular the German, governments. More precisely: the report proposes funding the promotion of structural reforms through arrangements of contractual nature within the 'integrated economic policy framework' (i.e. Building Block 3). Put simply, even the possibility of the new fiscal capacity to borrow and, hence, a full-fledged treasury function is 
suggested-a clear concession to the 'South', but seemingly as no more than a vision for the future.

As a sub-block of Building Block 2, but again rather defensively, the Interim Report addresses a safe and liquid financial asset for the euro area in order to break the vicious circle among the fate of the banks and the fate of the Member States-again a concession to the 'South'. A redemption fund and eurobills (short-term maturities) are mentioned as measures for the medium term-but, for instance, the 50 page blueprint on future EMU released by the European Commission [3] acknowledges that both require a treaty change. Full eurobonds are for the long term. Collateral could be required for the redemption fund, but no details are given with respect to types of collateral (gold, etc.).

\subsection{Building Block 3-Integrated Economic Policy Framework}

Under this heading the Interim Report comes up with the need to revitalise the reforms of the EU surveillance framework, promoting structural reforms through arrangements of a contractual nature, and strengthening macro-prudential policy. While the first two serve to improve the global competitiveness of Europe and the internal competitiveness of euro area Member States, the latter enhances the ability to prevent asset and credit bubbles.

The newly implemented surveillance measures should be made more visible, authoritative and be endowed with more impact. At the same time, the single market should be completed. What is more, structural reforms should be promoted through arrangements of a contractual nature such as limited, temporary, flexible and targeted financial incentives for reform steps previously identified within subcomponent 1-the surveillance framework. Finally, the Interim Report proposes strengthening macroprudential policies-optimally through making macroprudential policy tools available to the single supervisor, the ECB, and granting the European Systemic Risk Board (ESRB) a larger role in this process.

\subsection{Building Block 4-Ensuring Democratic Legitimacy and accountability}

The fourth and last Building Block refers to the issues of democratic legitimacy and accountability of the proposed euro area/EU governance structures. The Interim Report also admits that it has to carefully weigh up the roles of the European Parliament versus the national parliaments. Its guiding principle is "democratic control and accountability should occur at the level at which the decisions are taken" ([4], p. 8). However, this does not exclude benefits from closer cooperation of the European Parliament with the national parliaments.

In the following, this paper assesses and comments the proposals made and outlines potential recommendations in order to achieve a 'genuine Economic and Monetary Union' also considering the 'four Building Blocks'. For this purpose, it distinguishes -where possible-between short-term, medium-term and long-term measures. In Section 2, details of the Interim Report are systematically evaluated with scrutiny. Section 3 concludes.

\section{Is Europe's Search for a Genuine Economic and Monetary Union Misguided?}

The main merit of the Interim Report is that it truly hits the core of the political debate on the future of the euro. The time has come to talk more frankly than before about questions such as whether a single currency really requires a significant pooling of national policies and which players in the euro area are really willing to follow this logic $[5,6]$. A first taste of these kinds of discussions was conveyed by Wolgang Schäuble's now-famous call for an EU Monetary Affairs Commissioner equipped with rights to punch-through on national budgetary policies, comparable to his colleague from DG Competition (see [7]).

\subsection{Member States and Participating Institutions Try to Impose Their Own Interests}

This note does not necessarily intend to go as far as, for instance, Mussler [8], who argues that such a fundamental debate in the euro area does not seem to be really desired, although the leaders in June 2012 asked a group of four, namely the Presidents of the European Council, the EU Commission, the European Central Bank and the Eurogroup to outline the way to a 'genuine' monetary union [9]. But the Interim Report, as outlined above, and also the current longenduring controversial discussion about the details of the banking union (Building Block 1) make it very clear that a true political consensus on the direction is still lacking. Along a clear 'North-South' divide visible in the Interim Report, the respective governments are still trying to enforce predominantly their own interests which are well-known from the debates about the 'correct' way to manage the euro crisis. Hence, the Report adopts the shape of a two-handed approach or, as some might express it more bluntly, as a not too coherent convenience store.

Moreover, it seems as if all four presidents involved in the Interim Report have also been successful, to a certain extent, in enforcing their own and independent interests in settling additional political competencies in their institutions. In a wide array of areas, market governance is in the Interim Report, substituted by a governance by institutions which are shifted upwards to the EU-level and are well-known to have their own life and vested interests [9]. What is more, interest groups, such as banks and real estate brokers, are then able to delocalise from the local 
voters, who are their main competitors in impacting government policies [10]. This substitution might be seen either as a reflex consistent with the genesis of the financial crisis or as a consequence of the attitude of politicians to shift additional competencies at the EU level [11]. But, from this political constellation, a sensible governance solution can hardly emerge. The reason is that the proposed governance structure and its four Building Blocks (which are not even compatible with each other in all cases) are not incentivecompatible for all actors from a politico-economic point of view.

\subsection{The Congenital Defects of the EMU Cannot Simply Be Defined Away Politically}

What is more, the congenital defects of the monetary union cannot simply be defined away politically by a resolution. The euro area is still far from forming an optimal currency area, as has also been suggested by the Interim Report ([4], pp. 4-5). It explicitly addresses the basic fact that the textbook-style adjustment mechanisms to external demand shocks work much worse than in other currency areas. Crossborder labour mobility is low, both national product markets and factor markets are not sufficiently flexible: "Low levels of cross-country labour mobility and structural impediments to price flexibility make economic adjustment mechanisms less effective than in other monetary unions" ([4], p. 5). But this precise pattern is given as the 'EMU's unique feature' in the Interim Report which justifies a 'specific approach', i.e. implementing a common budget as an asymmetric shock absorber ([4], p. 4).

Does this not mean that the report considers the rigidities as given, and thus gives in much too early by still sticking to fiscal transfers to distressed countries? This would be a dangerous position, since, at the same time, parallel adjustment programmes are working quite successfully in the Southern Member States, and especially dangerous in the programme countries. Fiscal accommodation might even feedback negatively to reform activity [12].

\subsection{Independent National Fiscal Policies Are Generally Preferable to a Common Budget Because They Allow Risk Diversification}

The Interim Report leaves the use of the 'Euro budget' as open as other obvious questions, for instance, the ratio of the 'Euro budget' in relation to the general EU budget, from which it would be financed and the 'Euro budget's scope [8].

"Asymmetric shock absorption at the central level would represent a form of limited fiscal solidarity exercised over economic cycles, improving the economic resilience of the EMU" ([4], p. 5). This is not a specific conclusion of the Interim Report. Instead, it is widely assumed that a common currency makes it desirable also to have a common fiscal policy. However, if fiscal policy is a source of shocks, independent national fiscal policies are said to be generally preferable because they allow risk diversification. "The variance of a sum of shocks is the lower the lower the covariance among the individual components". Otherwise, we have a leadership problem: one weak or bad leader in the euro area can suffice to hole the euro project below the waterline [13]. This is especially so in our context because fiscal transfers to (a lot of) financially distressed countries would be highly correlated, which would then lead to a higher variance of GDP in the euro area.

Also, a reference to the US case may help. Gros [14] finds that the US federal budget comes up with much less insurance against state specific shocks than generally presumed, as the US Banking Union acts as a strong shock absorber. From this angle, the longterm stability of the EMU depends significantly more on the completion of plans for a European banking union than on the instalment of a 'fiscal capacity' for the euro area. In addition, the US budget is not an instructive example in the context of the Eurozone budget since it redistributes significantly between US regions at an amount of 30 to 40 percent of income differences, but does not compensate for more than 10 to 15 percent of GDP shocks to specific federal states [14]. Finally, using the US unemployment insurance system as a blueprint for a European one using the European budget would be misleading since the US system is mainly active in nationwide business cycle troughs, and unemployment benefits are simply not large enough ( 2 to 3 percent of GDP) to cope with GDP shocks of 10 percent and more, as seen during the euro crisis [14]. Cases such as Spain, with (structural) unemployment rates approaching 30 percent, reveal that a European unemployment insurance scheme would clearly risk perpetuating long-term unemployment in such member countries ([5], hysteresis).

Hence, the more fundamental question to ask is: how useful is the outlined transfer union? And how to persuade the 'North' of the sense of a severe sovereignty loss, which is necessary to ensure an ever-inflating 'euro rescue' and, more importantly, what necessary financial expenses are involved [8].

\subsection{The 'South' Sees a 'Euro Budget' as an Instrument of Redistribution}

Theoretically, there are two possibilities beyond the unrealistic readmission of floating exchange rates to improve the euro area's capacity of adjustment to external shocks. The first amounts to an increase of labour mobility or economic reforms to strengthen competitiveness. The second option is well-known to be politically more convenient and attractive to euro area politicians: the shocks can be mitigated by financial transfers to hard-hit countries. The four 
presidents of the mooted 'fiscal capacity' for the euro area, i.e. the 'Euro budget', could be instrumental in both options (Building Block 2). The German government wants to see it mainly used as an incentive tool to implement painful reforms in individual countries. France, however, interprets it as a general European instrument of redistribution beyond the permanent crisis fund ESM.

Given this background let us now again ask how useful the outlined transfer union is. The German government, for example, maintains that these transfers are not necessary because the economic reforms in several euro countries are well advanced. However, this is at best a half truth. That the current reduction of the economic divergence means that they have melted away permanently may well be doubted [15]. And the new instruments with which the EU is to bring national economic policies back on the right path show little effect. This is not only due to the lack of enforcement of sanctions. This is also because a fine-tuning of various parameters of economic policy by pan-European actors and institutions is simply not possible [8].

Hence, we must fear that the euro area is further from a 'genuine' monetary union than ever before, and that is quite logical. The question now, is rather, how many compromises will the currency union be able to stand in its current form?

\subsection{On the Necessity of a European Supervisory Authority}

In Building Block 1 and also throughout the text, the Interim Report argues in favour of a supra-national European supervisory authority. The usual argument is that national supervision of banks leads to 'regulatory capture' (which is not necessarily weaker at the EU level, [10]), and thus to a vicious circle. However, this could also be prevented by limiting the share of domestic government debt in the domestic banks' portfolios (i.e. the Weidmann-proposal) (see [16]). Needless to say, the financial distress of most southern euro area governments cannot be traced back to any necessity to support their banks. What is more, a large extent of the knowledge relevant for supervisors is of local nature, and the internal effects of the financial crisis were significantly more devastating than the external impacts. Thus, national supervisors had a larger interest in adequate supervision than foreign authorities.

Finally, the Interim Report favours a 'level playing field' ([4], pp. 2-3). However, generally speaking, this is not at all optimal from an economic perspective. There are important reasons not to enforce equal conditions on these markets: national authorities are sometimes better informed, national banking systems have different profiles and needs. Finally, yardstick competition in regulation is well-known to foster innovation and contributes to diversification of regulat- ory risk, i.e. risks of regulatory error [17].

The Interim Report diametrically contradicts the recommendations of the De Larosière Report on Financial Supervision in the European Union: 'While the Group supports an extended role for the ECB in macro-prudential oversight, it does not support any role for the ECB for micro-prudential supervision', a report which has been requested by the 'EU' itself (see [18]).

\subsection{The Interim Report: Further Points of Discussion}

The Interim Report claims that monetary policy is overall responsible for common shocks ([4], p. 5). This might be true in the long run, but in the meantime we are stuck in a clear re-nationalisation of monetary policies in the euro area (see the debate organised by The Economist on the pros and cons of debt mutualisation as an element of future Eurozone governance among Belke, and de Grauwe [19]). The exit from these unconventional policies is probably more demanding than envisaged by the report, as argued earlier. What is more, the Interim Report is contradictory in itself by stating that '(in) the EMU, the response to a symmetric shock affecting all countries simultaneously should primarily be provided by monetary policy' ([4], p. 5) but at the same time it is well-known that the credit crunch has been very selective, i.e. 'South' bound and precisely for this reason, monetary policy has become re-nationalised. This immediately implies that the current monetary policy assignment, having monetary policy supporting structurally distressed countries for years [20], stands in sharp contrast to the recommendations of the Interim Report itself.

"One of the functions of such a new fiscal capacity could be to facilitate adjustments to country-specific shocks by providing for some degree of absorption at the central level" ([4], p. 5). This suggests that country-specific multipliers are of a reasonable size. The European Commission shows in its recent Autumn Forecast that the IMF World Economic Outlook statement that the fiscal multiplier is much higher than assumed up to now is not tenable as soon as one implements further control variables in the estimated equation $[21,22]$. It is well-known that the ECB fiscal experts also come up with very different estimation results from the IMF. Unfortunately, a policy of austerity is accompanied by hardship, but it is, by definition, not possible to grow out of a current account deficit. And, especially with respect to Spain, the Commission has already demonstrated huge flexibility in its magnitude and speed of fiscal adjustment. This much is clear: Without the EU-IMF programme (and the overly generous support by the ECB's monetary policy) fiscal adjustment would have had to happen much more quickly-due to the balance of payment restriction which is currently felt, for instance, by France. 
'Overall, the creation of an integrated financial framework (...) cannot be envisaged separately from steps towards more integrated fiscal and economic frameworks' ([4], p. 3). It is probably not correct to state that an integrated financial framework is not possible without more integrated fiscal frameworks. Here, the answer is to implement a kind of fiscal federalism as a form of EU governance structure [5].

'(A) fully-fledged integrated budgetary framework (...) will ensure sound budgetary policies at the national and European levels and thereby contribute to sustainable growth and macroeconomic stability' ([4], p. 4). Why and to what extent should a fullyfledged integrated budgetary framework necessarily ensure more sound budgetary policies at the national and the EU level, leading to growth, than it does in the status quo? A related point is the following: 'another important function of such a fiscal capacity would be to facilitate structural reforms' ([4], p. 5). Of course, the answer of the Interim Report is: positive incentives. But who guarantees that the rules of public choice and political economy do not apply in this setting? Why are the players on the EU-level which run all the new institutions proposed by the report more benevolent than the national ones, etc. [9]?

"(I)n the context of country-specific economic shocks, the response falls primarily on national budgets" ([4], p. 5). But the Interim Report does not take into account that asymmetric shocks emerging in a currency union should not and cannot be automatically absorbed by national budgets. Shocks are often regional but not necessarily national in nature. Exactly for this reason we advised against national stability funds when asked by the European Parliament in $1998[22,23]$. Hence, regionally flexible goods and factor markets are necessary ingredients.

'A well-functioning shock absorption function would require a further degree of convergence between economic structures and policies of the Member States' ([4], p. 5). Is this not an internal contradiction since the Interim Report argues that a new central shock absorber is needed because reforms are lacking and the degree of reform significantly differs among Member Countries? Expressed differently, I do not see any envisaged stop of the new centralised shock-absorber as soon as the necessary degree of reforms is reached by using this new fiscal capacity.

' $(T)$ he pooling of some short-term sovereign funding instruments (e.g. treasury bills) on a limited and conditional basis could be examined further' ([4], p. 6). It can be argued in different contexts such as Eurobonds and/or OMTs that confidence in the conditionality of even temporary 'pooling' might be misguided $[20,24]$. Moreover, it potentially contradicts principles of democracy because it necessitates adhering to rules with which national parliaments are not necessarily compliant (Building Block 4).

"(A)n integrated economic policy framework contributes to avoiding the large and rapid buildup of im- balances" ([4], pp. 6-7). The ability to handle asset and credit bubbles through the proposed measures is not guaranteed with an eye on the commitment to a very accommodative monetary policy; this drawback is not necessarily compensated by more prudential policy tools (Building Block 3).

This is only a very selective choice of questions and caveats. There are certainly more of them, for instance, whether 'completing the single market' in the Interim Report means tax coordination instead of tax competition in view of the alleged Irish 'tax dumping' activities; or whether the integrated economic policy framework and the implied coordination mechanisms are explicitly said to be open to Member States that have not introduced the euro right now ([4], p. 7). Should this also be valid with respect to Building Block 1 , i.e., the components of a banking union? Even so, the UK and some non-euro Scandinavian countries had some incentive to financially support Ireland during the crisis.

Starting from the working assumption of the Interim Report ([4], p. 8) that "(t)he governance framework would also benefit from an active and open social dialogue", it appears overall worthwhile to have a detailed look at differences in the visions of EU governance between the 'North' and the 'South' of Member States [19].

\section{Different Governance Visions Emerging from the Ongoing Eurozone Crisis-The "North" and the "South"}

\subsection{Introductory Remarks}

The European summit that ended on 29 June 2012, declared that it was "imperative to break the vicious circle between banks and sovereigns". Markets revived on the hope that the leaders were finally ready to act to deal with the threat to the euro, and then soon lost heart amid the cacophony of rival interpretations about what had been agreed. Still, the leaders had identified the right issue: weak banks and weak sovereigns are like two bad swimmers that are pulling each other under water [25].

But which one should be saved first? Proponents of the "Southern view" like, for instance, Paul De Grauwe [19] tell us to start with the sovereigns, by throwing them the lifejacket of joint-issued debt. In effect, richer countries would guarantee at least part of the debt of weaker ones (Building Block 2).

Representatives of the "Northern", and especially the "German view", reckon instead that it is better to start by saving the banks (Building Block 1). This would be done through stronger central supervision and the mutualisation of some liabilities in the banking sector, for instance through a joint fund to wind up failing banks and provide a Europe-wide guarantee of bank deposits. In effect, depositors in solid banks would be guaranteeing the savings of those in more fragile ones. 
Following the identification of different and opposing views contained in the Interim Report above, this section finds it adequate to build upon a highly stylised, but widespread, definition of the "Southern" and the "Northern" view. The former usually comprises countries like Greece, Italy, Portugal and Spain and, quite frequently, also France. The latter is often used synonymously with the "German" view and also includes countries like Austria, Finland and the Netherlands and, to a lesser extent, also France. Since the exact characteristics of both views may still remain unclear, let us outline them in the remainder of this section more deeply.

Both sides-the "North" and the "South" agree on many things, such as the current threat to the survival of the euro. They both recognise the danger that debt mutualisation could bring moral hazard and higher costs for creditor countries. For representatives of the "Northern view" there is no getting around these problems. For the "South", though, these risks can be removed, or at least mitigated, through careful design of the system as expressed by the Interim Report. For instance, the Eurozone could impose conditions on countries seeking the benefit of jointly issued debt (Building Block 2).

The "South" sees the main threat to the Eurozone as coming from the fear and panic that can suddenly raise borrowing costs and push countries into insolvency. The "North", on the contrary, reckons the principal menace stems from removing this market pressure too quickly, which lets it dampen the need to reform.

Both speak of the political backlash that the crisis creates. For the "South" it is excessive austerity in debtor nations that will be resisted; for the "North" it is excessive liabilities in creditor states that can cause resentment.

In some ways, though, they are not so far apart. The "North" concedes that it is necessary to have some mutualisation of debt, if only to recapitalise banks [5]. The "South" accepts that debt mutualisation must be limited to avoid moral hazard [19].

\subsection{Opening-Contrasting the "Southern" and the "Northern" Views}

In the following, the basic ingredients of the "Southern" and the "Northern" views are contrasted with each other.

\subsubsection{The "Southern" View: Some Basics}

The main argument of the "South" runs as follows. Since the 1970s, economists have warned that a budgetary union would be a necessity for a sustainable monetary union. But the founders of the Eurozone had no ears for this warning. It is now patently clear that they were mistaken and that the governments of the euro area member countries face the following hard choice today: either they fix this design failure and move to a budgetary union; or they do not fix it, which means that the euro will have to be abandoned. Although analysts such as Paul de Grauwe were sceptics about the desirability of a monetary union during the 1990s (contrary to [26]), the same author now takes the view that we cannot properly manage a deconstruction of the Eurozone [19]. A disintegration of the Eurozone would produce huge economic, social and political upheavals in Europe. If the euro area governments want to avoid these, they have to look for strategies that move us closer towards a budgetary union (Building Block 2).

A budgetary union, like that in the US, appears to be so far off that there is no reasonable prospect of achieving this in the Eurozone "during our lifetimes". Does that imply that the idea of establishing a budgetary union and thus a 'genuine Economic and Monetary Union' is a pure chimera? De Grauwe [19] argues that this drastic assessment is not at all valid and that there is a strategy of taking small steps that can guide us in the right direction. But before this strategy can be outlined and compared to the Interim Report, it is-according to the "Southern" viewimportant to understand one of the main design failures of the Eurozone. This will deliver some information about what exactly has to be fixed.

The "Southern" argument starts from the basic idea that Eurozone governments issue debt in euros which is a currency they cannot control. As a result, and in contrast to "stand-alone" countries like Britain, they endow bondholders with a guarantee that the cash to pay them out at maturity will always be available [27].

The fact that governments of the Eurozone are not able to deliver such a guarantee to bondholders makes them vulnerable to upsurges of distrust and fear in the bond markets. These can trigger liquidity crises that, in a self-fulfilling way, can drive countries towards default, forcing them to apply austerity programmes that lead to deep recessions and ultimately also to banking crises [19]. According to the "Southern" view, this is not to say that countries that have overspent in the past do not have to apply austerity. They will have to. It is rather that financial markets, when they are driven by panic, force austerity on these countries with an intensity that can trigger major social and political backlashes that policymakers may not be able to control. The effects are there to see in a number of Southern European countries [19].

Their previous diagnosis of a design failure of the Eurozone leads proponents of the "Southern view" to the idea that some form of pooling of government debt is necessary to overcome this failure (Building Block 2). By pooling government debt, the weakest in the union are shielded from the destructive upsurges of fear and panic that regularly arise in the financial markets of a monetary union and that can hit any 
country. "Those that are strong today may become weak tomorrow, and vice versa" [19].

Representatives of the "South" agree that, of course, not just any type of pooling of national debts is acceptable. They acknowledge that the major concern of the strong countries that are asked to join in such an arrangement is moral hazard-that is, the risk that those that profit from the creditworthiness of the strong countries exploit this and lessen their efforts to reduce debts and deficits. This moral hazard risk is the main obstacle to pooling debt in the Eurozone. The Interim Report is silent in this respect; it does not refer to any form of pledges such as gold. The second obstacle is that, inevitably, the strongest countries will pay a higher interest rate on their debts as they become jointly liable for the debts of governments with lower creditworthiness. Thus, debt pooling must be designed in such a way as to overcome these obstacles.

Moderate proponents of the "Southern" view, apparently in agreement with the Merkel government, agree that there are three principles that should be followed in designing the right type of debt pooling [19]. First, it should be partial-that is, a significant part of the debt must remain the responsibility of the national governments so as to give them a continuing incentive to reduce debts and deficits. Several proposals have been made to achieve this (among them [28] and [29]). Second, an internal transfer mechanism between the members of the pool must ensure that the less creditworthy countries compensate (at least partially) the more creditworthy ones [19]. Third, a tight control mechanism on the progress of national governments in achieving sustainable debt levels must be an essential part of debt pooling. The Padoa-Schioppa group has recently proposed a gradual loss of control over their national budgetary process for the breakers of budgetary rules [30].

Proponents of the "Southern" view acknowledge that the Eurozone is in the midst of an existential crisis that is slowly but inexorably destroying its foundations. They immediately conclude that the only way to stop this is to convince the financial markets that the Eurozone is here to stay [19]. Their main argument is that debt pooling which satisfies the principles outlined above would give a signal to the markets that the members of the Eurozone are serious in their intention to stick together. Without this signal the markets will-according to their argumentnot calm down and an end to the euro will be inevitable [19]. In the words of Angela Merkel: these policies are without alternative.

Materially, the "Northern" view described below represents the accumulation of a multitude of reactions of the "North" to these much more activist "Southern" proposals of several kinds of debt mutualisation, which have frequently been pushed forward since the start of the euro crisis.

\subsubsection{The "Northern" View: Important Facets}

One of the fundamental principles of the "Northern" view is that the mutualisation of the Eurozone's debt to bring about the convergence of interest rates as proposed within Building Block 2 of the Interim Report will not, in the long run, tackle the roots of the problems. Instead it has the potential to sow the seeds of an even larger crisis in the future $[16,31]$. They allude to what happened in the early years of the euro when interest rates largely converged. Paradoxically, perhaps, this paved the way for a greater divergence of national fiscal policies. A reckless lack of discipline in countries such as Greece and Portugalbe they more (Greece) or less (Portugal) insolventwas matched by the build-up of asset bubbles in other member countries such as Spain and Ireland, deemed merely illiquid. Structural reforms were delayed, while wages outstripped productivity growth. The representatives of the "Northern" view stress that the consequence was a huge loss of competitiveness in the periphery, which will by definition not be resolved by the mutualisation of debt as proposed in Building Block 2 of the interim report [5].

Debt mutualisation can take different forms. One is to mutualise new sovereign debt through Eurobonds ([28], more than 7 variants). Another is to merge part of the old debt, as advocated by the German Council of Economic Advisors [29] with its proposal for a partly gold-backed European Redemption Fund. A third means is to activate the Eurozone's "firewall" by using the rescue funds (either the temporary European Financial Stability Facility or the permanent European Stability Mechanism) to buy sovereign bonds on the secondary (or even primary) market, or to inject capital directly into distressed banks. Indeed, the ECB is already engaged in a hidden form of mutualisation-of risk if not (yet) of actual debtthrough its programmes of sovereign bond purchases (the Securities Market Programme, SMP, and the announced conditional Outright Monetary Transactions, OMTs) and its long-term refinancing operations for banks.

The view of the "North" is that almost all of these are bound to fail either for economic or political reasons, or both. The governments of even financially strong countries cannot agree to open-ended commitments that could endanger their own financial stability or, given that they are the main guarantors, that of the bailout funds. And the danger of moral hazard is ever-present [5].

Proponents of the "Northern" view, point to the fact that any form of mutualisation involves an element of subsidy (the Interim Report speaks of an element of limited solidarity), which severely weakens fiscal discipline: the interest rate premium on bonds of fiscally weaker countries declines and the premium for stronger countries increases. Fiscally solid countries are punished and less solid ones, in turn, are 
rewarded for their lack of fiscal discipline and excess private and public consumption.

If yields are too low, there is no incentive for private investors to buy sovereign bonds. The countries risk becoming decoupled from the capital markets permanently, and the debt problems become increasingly structural.

This is true also for the ECB's bond-buying announcements and activities. The credit risk is thus simply rolled over from the bonds of the weaker countries to those of the stronger ones (depending on the buyback price), and the ECB is made responsible for its liability. Over time, the ECB's measures might even be inflationary. Having the rescue funds to buy bonds is little different, except that they lack the landing capacity to be credible. If they are given a banking license, as demanded by the "South" (for instance, by French President Hollande), it would be no different from having the ECB buy bonds directly.

What about the European Redemption Fund (ERP) from the "Northern" perspective? This type of fund could be of particular help to Italy, which could unload half of its debt. But its partners could not force Italy to tax its citizens to ensure it pays back the dormant debt. And with the assumption of debt, the credit rating of Germany might drop due to the increase of the German interest burden. The pressure on Italy and Spain to consolidate their budgets sustainably would be reduced. The problems of Greece, Ireland and Portugal would not be resolved, since these countries are unlikely to qualify for the ERP.

On top of moral hazard, there are the political obstacles, which would be most acute in the case of Eurobonds-the "genuine euro area safe and liquid asset" proposed by the Interim Report on p. 6. For instance, Germany demands political union before Eurobonds can be considered. But this is sometimes said to put the cart before the horse: a political union would be created simply to justify Eurobonds [32]. Advocates from the Merkel government like Finance Minister Wolfgang Schäuble say that treaty changes and high-level political agreements would be sufficient to ensure that euro area member countries comply with all decisions taken at the euro area level (see again his recent "Waehrungskommissar" proposal). But the experience with Greece's adjustment casts severe doubt on such optimism. (Although recently, after Angela Merkel came back from a visit to China, surprisingly, some optimism towards the Greek case re-emerged in German politics as reflected in concerted media action in early autumn 2012).

Even a quick glance at the World Bank's databank of "governance indicators" shows that differences between Eurozone members, on everything from respect for the rule of law to administrative capacity, are so great that political union is unlikely to work, at least in the next couple of years. It follows from the perspective of the "North" that the case for Eurobonds is extremely weak.
According to the "Northern" or "German" view, the introduction of Eurobonds would have to, in principle, be backed by tight oversight of national fiscal and economic policies. This is correctly reflected in the Interim Report under the heading "Integrated economic policy framework", i.e. Building Block 3. But this view neglects that there is no true enforcement as long as the Eurozone members remain sovereign. The Interim Report argues accordingly that in this case the pivotal role of national parliaments has to be maintained ([4], p. 8, President of the European Council).

Intervening directly in the fiscal sovereignty of member states would require a functioning panEuropean democratic legitimacy, but we are far from that (Building Block 4). Voters in Southern countries can at any time reject the strong conditionality demanded by Brussels, while those of Northern countries can refuse to keep paying for the south. And either can choose to exit the Eurozone [32].

The emphasis on pushing through a fiscal union as a precondition for debt mutualisation means the debate, at least in Germany, has become a question of "all or nothing": either deeper political union (i.e. Building Block 2) or deep chaos [5]. This unnecessarily narrows the strategic options for the players and causes the permanent "North-South" divide described in this section (which is also mirrored in the Interim Report), which is severely hampering the realization of a "genuine" monetary and economic union.

But this paper argues that there is in fact an alternative option to the notion of cooperative fiscal federalism involving bailouts and debt mutualisation: competition-based fiscal federalism, of the sort successfully operating in the US, Canada and Switzerland, among others. These countries have largely avoided serious and sustained public debt in their component states. The sub-federal entities faced with insolvency have a great incentive to take early corrective actionwithout having to force the member-states into a corset of centralised fiscal policy coordination. This view seems to be a good compromise between the "Southern" and the "Northern" view.

To achieve this sort of federalism, it is necessary to separate the fate of the banks from that of the sovereigns. What is needed is not a fiscal union in first instance, but a banking union (Building Block 1). It should be based on four elements: a reformed banking regulation with significantly higher equity capital standards; a European banking oversight with farreaching powers to intervene; a banking resolution fund; and a European deposit insurance scheme. This has also been recognized and acknowledged by the Merkel Government.

A banking union-a less comprehensive, more clearly delineated and rather technical task-should be far better accepted in the "North" than the Europeanisation of fiscal policy as a whole. This is precisely because it touches upon only a small fraction of the 
fiscal policy areas which have to be subordinated to central control in a fiscal union.

Obviously, a central resolution authority has to be endowed with the resources to wind up large crossborder banks. Where does the money for this come from? In the long run, the existence of a resolution authority goes along with a deposit insurance scheme for cross-border banks. This should be-according to the "German" view-funded partly by the banking industry. But there should also be a backstop by the euro area governments provided through the EFSF or the ESM in order to cope with situations of systemic bank failure [33].

As a temporary transition measure, however, limited debt mutualisation may then be necessary-but only to recapitalise banks that cannot be sustained by their sovereigns. However, the amounts required are much smaller than for, say Eurobonds [33].

With the banking system and the debt crisis thus disentangled, banking-sector losses will no longer threaten to destroy the solvency of solid sovereigns such as Ireland and Spain. Eurobonds will then not be needed, and neither will the bailout of sovereigns. The debt of over-indebted states could be restructured, which means that the capital market could exert stronger discipline on borrowers [5].

\subsubsection{Summary}

There are at least two questions left which have not yet been covered in this paper and will be answered in the following sections. If the banking sector really is to be stabilised, a solution will surely have to deal with the devalued sovereign debt that some are holding. Would the banks not be better off holding at least some Eurobonds instead of, say, Greek or Spanish bonds? That said, "Southern" economists who advocate Eurobonds need to find a way of making them politically acceptable. And how much political union is feasible, or even desirable, just for the sake of a single currency that many never loved? (and also, where does the burden end up?).

\subsection{Rebuttal-Banking Union and Other Issues}

\subsubsection{The "Southern" View: Fiscal Debt Mutualisation to Protect Banks from Sovereign Failures}

It is quite surprising to find the German government on the "against the debt mutualisation" side in this debate. In fact, for instance, de Grauwe [19] argues that a couple of German politicians develop an eloquent plea for mutualising the debt in the context of a banking union [5]. As proponents of the "Southern" view recognise, the banking union that the "North" defends (and that the "South" also defends) requires "a backstop provided by the euro-zone governments". This is nothing but an implicit joint liability of the Eurozone governments to commit future taxpayers' money to a systemic banking crisis.

A second surprise for "Southern" governments is that Germany is not be willing to apply all the objections it has levied against the issue of Eurobonds to his proposal for an implicit Eurobond issue to defend the banks.

The "Southern" policymakers emphasise that promising future support to banks (Building Block 1) surely creates similar moral hazard risks as promising future support to sovereigns. There is no reason to assume that the latter are more serious than the former. According to their view, they find it strange that proponents of the "Northern" view do not apply his stern moral hazard analysis to banks in the same way as they do to the sovereigns. They seem to believe that bankers are more trustworthy than sovereigns [19].

"Southern" euro area governments acknowledge that there is a serious problem of democratic legitimacy in any scheme that ties the hands of future European taxpayers (Building Block 4). But they claim that the same problem arises if such taxpayers are called upon to save banks or sovereigns. In this vein, de Grauwe [19] represents the "Southern" view and argues that the "North" tries to extricate itself from this difficult problem by stating that the bank-related debt mutualisation it proposes will have only small consequences for future taxpayers [5]. What is more, the total bank debt in the Eurozone is three times the government debt. Potential future liabilities are certainly not small in his scheme, de Grauwe argues.

Finally, there is the "putting the cart before the horse" argument often heard in Germany: that we have to wait for a political union before we can start issuing Eurobonds. But why does that argument not count when, in the absence of a political union, Germany, for instance, proposes setting up a banking union in which one of the first steps is installing a banking oversight mechanism? A banking union is not just a technical matter, as the "North" often states (see Section 3.2.2). The "South" claims that it requires the same political infrastructure to enforce decisions taken at the European level and to give taxing powers to the European institutions that will be called upon to sustain the banking sector [19].

Proponents of the "Southern" view permanently emphasise that they do not want to be misunderstood on this issue. They concede that the problems that their "Northern" counterparts evoke are real ones [19]. However, their criticism is that the "North" emphasises these problems when discussing one form of debt mutualisation-the issue of Eurobonds-and ignores them when proposing its own form of debt mutualisation [19]. It might also be worth mentioning the German opposition to a third form of mutualisation, namely deposit insurance.

Moreover, the "South" argues that "problems are there to be solved". The moral hazard problem is acknowledged to be a difficult one, but the "South" claims that its impact can be minimised. In Section 
3.2.1, some principles have already been formulated to reduce this moral hazard risk. One was that the mutualisation should be partial; the other was that it should be linked to transfers of sovereignty. These are the conditions the "North" seems to stress while despairing that they can be met today [19].

The "Southern" Eurozone governments call it a fundamental problem that-in compliance with the German view-the community of euro area member states must wait for a political union before it can think of mutualising the debt [19]. But how do we start a political union? The "South" argues that "just waiting will not make it happen". Hence, there is only one other approach from the "Southern" perspective: taking small steps towards political union [19]. At some point the content of political union should be explained-as is done in the Interim Report. The interesting point from the perspective taken in this paper is that it could be seen as the fourth dimension of the October 2012 report by the 'four presidents' i.e. the legitimacy and accountability dimension (Building Block 4).

The "South" concedes that "North" and "South" can disagree on what these steps should be. But the "North" tells it that the first and only step should be a limited mutualisation of the debt so as to sustain a banking union. The "South" is in favour of the "North's" banking union (Building Block 1). But it disagrees when the "North" claims that this is all that is needed and that the capital markets will take care of the rest by "exerting stronger discipline on borrowers" [31]-the efficient market theory is a deus ex machina to save the euro.

Once we take the first step, we will be confronted with the need to take other steps, the "South" further argues. According to the "Southern" view, the banking union protects the sovereigns from bank failures, which is a good thing. But it does not protect the banks from sovereign failures. These will continue to occur in the Eurozone with or without efficient markets [19]. Thus by hitting the banks, a sovereign debt crisis will force other Eurozone governments to support the banks, and thus the sovereigns. Then, the "South" argues, we will have come full circle. In order to support the banks, sovereigns will be forced to support each other. One step, i.e. Building Block 1, necessarily leads to a second step, i.e., Building Block 2. The "South" is iteratively proposing that we may as well take that second step now (see most recently French President Hollande at the EU Summit in Brussels on 18 October 2012).

3.3.2. The "Northern" View: No Debt Mutualisation as Long as "South-North" Divide Is Structural

As pointed out in Section 3.2.1, the "Southern" view regrets that Eurozone countries do not have the control over the European Central Bank which countries such as Britain and America have over their central banks. But according to the "Northern" view, that is not a flaw in the system. Instead, it was designed that way in order that governments should not be able to inflate their way out of trouble. In Britain and America there is-according to the "Northern" view a tango between the central bank (which cannot become illiquid because of the possibility of inflating) and with the government (which cannot become insolvent, given the possibility of imposing and increasing taxes). De Grauwe [19] implicitly unveils the "Southern" view of the role monetary policy should play in accompanying debt pooling when he says that the main task of a central bank is to "give a guarantee to bondholders that cash is always available to pay them out..." According to the proponents of the "Northern" view, he thus directly complies with the wishes of the rating agencies and US-portfolio managers to orchestrate sovereign bond purchases and bazookas in the form of long-term refinancing operations by the ECB.

As a starting point, the "North" points to the fact that macroeconomic evidence is clearly not compatible with the "Southern" view that those "who are strong today may become weak tomorrow and vice versa". In practice, the opposite has happened. This is because of diverging long-term trends between Southern and Northern Eurozone countries in the quality of governance, the rule of law, labour market performance, growth and current account imbalances (Building Block 3). These differences have become structural and long-lasting in the case of several Eurozone countries. Spain, for instance, has arguably been suffering from very high structural unemployment for decades and will be additionally hampered in the decades to come by its excessive investment in construction [14].

The main problem debt pooling is supposed (by the "North") to solve is that, given the 'sudden stop' in cross border capital flows, some Southern member states must close their current account deficits as they have actually started to do in recent months. So, in the short run, they need to reduce consumption, and in the long run, they need a shift of resources to exports via lower wages and structural reform (Building Block 3). But debt pooling will not help them make these adjustments (Building Block 2).

In the same vein, the "North" notes that the relatively good performance of the Spanish economy in the years 2010 to 2011 was due to the slowdown of the adjustment in both the government accounts and the housing sector. This delay was thus the result of a lack of leadership, and is not an argument for debt pooling. Its long-term costs are now becoming apparent. The huge construction overhang implies losses that the banking sector may be facing once adjustment is complete (see the macro-prudential policies proposed in Building Block 3). It corresponds with the amount of real resources wasted by expenditure that was financed mostly by loans. It far exceeds the 
provisions and the write-downs as yet accumulated by the Spanish banking system. If debt-pooling were in place, Spain's banks might still be making those loans.

The "South" on some occasions outlines hard budget constraints to accompany debt pooling [19]. Its representatives propose binding mechanisms of compensating the more creditworthy countries and controlling the behaviour of those that are less so. But, according to the "Northern" view, historical experience gives reason to doubt that this will work-for several reasons.

One reason is that Spanish foreign debt is currently the greatest risk to the Eurozone, and it is essentially private. As long as the private sector has access to the ECB system at interest rates that are below the market rate, the correction of external imbalances through real internal devaluations will not take place, or if it does, at least not in sufficient quantities. The "South's" approach would require not only public debt limits but also private debt barriers to bring about such a correction, but that would be an absurd endeavour.

The "South" should draw some lessons from the current conduct of monetary policy. The latter already uses debt pooling, of a sort. The quality of the collateral that the ECB accepts varies considerably from country to country. In the case of the ECB's lending to Greek banks, it consists of doubtful private Greek assets and Greek government debt whose value depends on election results, as has been recently observed. Thus the ECB acts as a central counterparty for cross-border lending which incurs risks along national lines [34]. Risk mutualisation could well, if things go wrong, turn into full debt mutualisation, and lead to conflicts between member states. It provides an advance warning of how debt pooling could lead to the disintegration of the Eurozone.

This is precisely why the Interim Report argues with respect to its Building Block 2 that in the long run "...(i)n the EMU, the response to a symmetric shock affecting all countries simultaneously should primarily be provided by monetary policy, whereas in the context of country-specific economic shocks, the response falls primarily on national budgets" ([4], p. 5, President of the European Council).

\subsubsection{Summary}

For "Northern" governments like the German one, the mutualisation of debt is just another form of subsidy and bail-out for which markets clamour, be it the overt help given to Greece, or the more discreet liquidity provided by the European Central Bank.

The fact that there is a loud chorus demanding subsidies does not, in Germany's view, make it right [5]. The Merkel government argues that assistance does not help countries make the necessary macroeconomic adjustment in either public or private borrowing. Safeguards and conditions as stand-alone measures will not work. Anything that puts off the rebalancing of the current-account deficit only builds up the forces for the disintegration of the Eurozone. Watching the "South" borrow and spend themselves into bankruptcy and then bailing them out is both immoral and irresponsible.

In their rebuttal, "Southern" governments target what they regard as the contradiction in the "North's" position, rejecting debt mutualisation while supporting a joint Eurozone backstop for the banking sector [19]. Are banks any more trustworthy than sovereigns?

The "South" usually argues, moreover, that mutualisation of banking liabilities will inevitably be followed by the pooling of debt. Banking union on its own, for instance de Grauwe [19] notes, would protect the sovereigns from banking crises. But it would not protect banks from sovereign-debt crises. If banking union (Building Block 1) must be followed by the fiscal sort (Building Block 2), it would be best to do it at the same time, the "South" argues.

But many questions remain unanswered-the Interim Report is also no exception to this rule. Some German politicians identify the tendency of the single currency to push the economies of its members apart [5]. If all countries are to fend for themselves, as some proponents of the "German" view assert, would they not be better off restoring their own national currencies so that macroeconomic adjustment can take place more painlessly (a point directly related to Building Block 3)? As a blogger in The Economist Online puts it, "The south will end up having to leave the euro to save what's left of its economy" (see [35]).

For its part, the "South" indicates that more steps will have to be taken beyond the mutualisation of debt and banking liabilities, including the transfer of sovereignty to Brussels [19]. But what is the limit of all this? "This is not an economic problem. It is a cultural problem. We are experiencing mutinies by various groups among the passengers and deck and engine room crews" (see [36]). If Southern governments are right in saying that the banking union should be the first step towards the eventual creation of the United States of Europe, when will the citizens be asked to give their opinion of the whole project? Clearly, Building Block 4 is addressed here.

\subsection{Closing-The Way Forward}

3.4.1. "South": A Monetary Union Cannot Last without Debt Mutualisation to Avoid Deflation

The key issue is this: can a monetary union last without some form of fiscal union? Economists have been debating this issue for decades. It seems at least to the "South" that the consensus among them is that a monetary union without some form of fiscal union will not last. This view is clearly shared by the Interim Report.

What kind of fiscal union is necessary to sustain a 
monetary union (Building Block 2)? "Southern" governments tend to argue that such a fiscal union must have two components. First, it must have some insurance component, i.e. there must be some transfer mechanism from regions (countries) that experience good economic times to regions (countries) that experience bad times (the Interim Report alternatively proposes a central budget with similar functions). According to the "South", the US is often seen as a successful monetary union, partly because the federal government's budget performs the role of insurance. "Southern" governments are also eager to point out that the opponents will not cease to stress that such an insurance mechanism creates moral hazard issues. But that is the case with all insurance mechanisms. Representatives of the "Southern" view argue, as an analogy, that one generally also does not conclude that people should not have fire insurance because such insurance creates moral hazard, i.e. it will lead to more fires.

The second component of a fiscal union is some degree of debt pooling. Economist defending the "Southern" view have argued that this is necessary because in becoming members of a monetary union countries have to issue debt in a "foreign" currency and therefore become more vulnerable to upsurges of distrust and fear in financial markets. These can, in a self-fulfilling way, push countries into a bad equilibrium that makes it more difficult for them to adjust to imbalances [19]. Of course, debt pooling does not solve these fundamental problems (as "Northern" governments suggest that the "South" believes), but it avoids pushing countries, like Spain today, into a deflationary spiral that causes their debt problems to deteriorate, not improve.

Thus monetary union and fiscal union (including some degree of debt mutualisation) are the opposite sides of the same coin. As was made clear earlier in this paper, the proponents of the "Northern" view like to refer to history. The "Southern" economists also do this. According to them, there are no successful monetary unions that are not embedded in a fiscal union that includes debt mutualisation.

Some economists, especially in Northern Europe, continue to argue that one can have a monetary union without a fiscal union. Paul de Grauwe [19], for instance, reduces the "Northern" view to something like "all we need is discipline (a fiscal compact?), including a credible no-bail-out clause. If we allow governments to default, financial markets will do their work in disciplining these governments". According to both the "South" and the Interim Report, this view can certainly not be taken seriously any longer [19]. This is because financial markets are utterly incapable of applying the right discipline to governments. When markets are euphoric, as they were during the ten years before the crisis, they intensify indiscipline by giving incentives to borrowers and lenders alike to create excessive debt and credit. Since the crisis erupted, financial markets have been in a continuous state of fear and panic, leading them to apply excessive discipline that has led nowhere except to increasing debt burdens [19].

When the dust in this debate has settled, it willaccording to the "Southern" view-be clear that the greatest obstacle to debt mutualisation and the continuing existence of the Eurozone is a lack of trust -which has not yet been eliminated, as the Interim Report clearly proves. "Northern European countries distrust southern European countries and have propagated the myth that the North is morally superior compared with the corrupt regimes in the South. In Northern mythology, Southern European countries are seen as utterly incapable of setting their house in order. Lending money to these countries is pouring the hard-earned money of virtuous German savers into a bottomless pit. Southern European countries distrust the North and have propagated the myth that Northern European countries are out to dominate them and to impose a harsh and inhumane regime on helpless people. Mutual distrust is growing and is left unchecked because in all these countries few people stand up to call these myths just myths" [19].

The idea that a successful monetary union needs two essential ingredients is common to the "North" and the "South". One is mutual support, the other is a mutual control system. "Mutual support is essential to create a sense of belonging, without which no union can survive. In that sense a monetary union is like a marriage" [19]. It cannot survive if the partners tell each other that they should not count on help when they are in trouble. Mutual control is also essential in order to avoid opportunistic behaviour by those who receive help [19]. Unfortunately, the Interim Report claims that this control should take place by way of plans and newly designed mechanisms, but not through markets.

Mutual support and control can only be organised effectively in the context of a political union, the "South" claims. That is the institutional environment in which support and control can acquire democratic legitimacy (Building Block 4) and become sustainable. Thus, the choice is clear: either the euro area becomes a country, or it disappears. There is nothing intermediate option. This view is also shared among the "South" and the "North".

\subsection{2. "North": Towards a Concept of Competition- Based Fiscal Federalism in the Eurozone?}

In Section 3.2.2, I set out the most important components of a competition-based fiscal federalism that would probably make Eurobonds (Building Block 2) unnecessary. These relate mainly to Building Block 1 . This is not because banking union is equivalent to Eurobonds (as claimed by de Grauwe [19] but because it would disentangle a banking and a sovereigndebt crisis. With a solid banking system in place, 
banking-sector losses would no longer threaten the solvency of solid sovereigns (such as Ireland and Spain), and the bail-out of less reliable sovereigns would no longer be necessary. That means there would be a lower chance that fundamentally sound sovereigns would suffer from a confidence crisis and rocketing risk premiums.

Proponents of the "Northern" view do not accept the argument of the "South", coined for instance by de Grauwe [19], that a banking union does not protect the banks from sovereign failures. In a banking union, the capital market could exert its disciplining influence more effectively than it does now. Debt restructuring for insolvent states would become more probable. The debtor state would lose its strongest asset (the claim that default would cause huge damage to the entire financial system) and creditors could not rely on taxpayers to recoup their money. This, in turn, would put governments with unsound finances under pressure to curb their deficits.

Instead they hint at a wide array of econometric studies showing a systematic relationship of sovereign bond yields and the anticipated sustainability of a country's public debt-at least in the medium term. They leave it to the Banca d'Italia's research department to come up with convertibility risk (measured by google-nomics counting google searches for euro area breakup), as an explanatory variable of Southern sovereign bond yield spreads over the German yield [37]. Only recently, the spread on Spanish bonds moved up after Mariano Rajoy, the Spanish prime minister, announced that he intended to relax Spain's deficitadjustment path; as when Italy decelerated its pace of reforms. Hence, proponents of the "Northern" view can sleep quite well with the idea that "capital markets will take care of the rest".

To eliminate the fragility from the banking system, we must establish a temporary, or even permanent European Resolution Authority (ERA), whose task would be to rehabilitate fragile banks across Europe, regardless of size. Weaker banks would receive a onetime injection of capital or be wound down, wholly or partly. This body should have the power to turn bank debt into equity capital. Creditors of ailing banks-but not the taxpayers, as de Grauwe [19] assumesshould, as far as possible, be made liable for their risky investments. In contrast with Eurobonds, which tend to cover many bad risks, a European deposit scheme based on funding from the banks themselves (in order to avoid taxpayers bearing the risk) would in the end embrace only stronger banks [33].

The "North" admits to the "South" that it is right to argue that the lack of a budgetary union, akin to the American system, is a design failure of the Eurozone. Proponents of the "Northern" view also strongly support the "South's" view that a proper application of the American system would prevent a costly disintegration-but most probably for different reasons. Since the US system prevents central-bank loans from being more attractive than market loans, it avoids permanent balance-of-payment imbalances between member states. In America, neither the individual state nor the private sector has access to the printing press to finance itself and can default. If the inhabitants of a state need to finance their currentaccount deficits, they have to offer attractive interest rates and provide sufficient collateral to private lenders from other American states [5].

Yet the "South" argues, essentially, that Eurozone countries' main problem is that they do not have direct access to the printing press [19]. According to the "North", and, thus, following the strange behaviour of rating agencies, which penalise members of the Eurozone simply for being part of the single currency. For too long the agencies rated countries too generously, pricing in a potential bail-out rather than basing ratings purely on macroeconomic fundamentals. This pattern made risk-free profits possible from risk-free speculation against sometimes hopelessly non-competitive member states. The "South" reinterprets this as a question of "panicked financial markets" in its mother of all arguments for debt pooling [19].

Especially according to the "Northern" view, the members of the Eurozone are intentionally kept away from the ECB to avoid them activating the inflation tax to finance themselves. The scope for an individual country to incur government debt is simply lower within a currency union than outside. This scope cannot be extended through debt pooling without risking the disintegration of the Eurozone [5].

But the "Northern" view contains a lot more. As a rule, the burden on bank balance sheets should be borne by the country of domicile and not-as in the case of Eurobonds-be passed on to other countries (Building Block 2). However, it is not clear whether and to what extent over-indebted countries will be capable of doing this. Using the rescue funds would make sense as a fiscal backstop. Subject to negotiation, a temporary debt mutualisation to cover the cost of bank recapitalisation would make sense, to avoid a larger and permanent mutualisation of sovereign debt. But only after a proper pan-European banking oversight has been finalised and implemented (Building Block 1 and [5]).

\subsubsection{Summary}

Throughout the Eurozone's debt crisis, many Europeans have looked across the Atlantic for lessons on how to run a successful monetary union. The European Commission boasts that, taken together, the Eurozone's fiscal deficit and debt are lower than America's. Yet the euro faces an existential crisis while the dollar, despite the troubles of the American economy, still remains a shelter.

So, how much banking and fiscal integration does the Eurozone need to restore stability (Building Blocks 
1 and 2)? And how much political unity does it need to maintain checks and balances, and democratic legitimacy (Building Block 4)? Looking at the US, "Southern" and "Northern" economists and politicians more or less agree on the need for some kind of federalised system to recapitalise, restructure or wind down ailing banks. That is where the "North" thinks integration should stop-in contrast to the Interim Report. The key lesson from the US is, in its view, that it pays to enhance market discipline on the states: as long as the banking system is stabilised at minimal cost to the taxpayer, over-indebted states can be allowed to go bust.

But proponents of the "South" (as well as the drafters of the Interim Report) think that this deals with only half of the vicious circle between weak banks and weak sovereigns, and therefore cannot work in the long run. In his view, what makes America and other monetary unions stable is a system of joint bonds and other forms of mutual insurance and internal transfers to redress economic imbalances [19].

Drawing a parallel with the US case inevitably leads one to consider the obvious difference: the US is a federal country; the Eurozone however is a collection of 17 separate states. De Grauwe [19] vividly addresses this point, which is an essential ingredient of the "Southern" view, directly in his final sentence: "The choice is clear: either the euro zone becomes a country, or it disappears. There is nothing in between." Section 3.4.2 does not speak much about the desirability of political union, but the "North's" vision implies that the Eurozone should remain a collection of sovereign countries, each guarding its taxpayers' interests by limiting their exposure to others.

Many in the active and engaged audience of European citizens reflect on the loss of national sovereignty and discretion that may be necessary to make the single currency work. From the floor we hear bloggers state: "the only way this could work is if all the countries agree on a common retirement age, welfare, unemployment, etc.", "Mutualisation of debt has to be tied to a real surrender of fiscal sovereignty. The reason is obvious: Only a complete fool would share his unlimited credit card with someone if he had no control over their spending", and "As long as there is no European army to force European countries to comply with directives (on budgets and spending) of a central authority, it will always be a game of bluff and brinkmanship." (see [38]).

\section{Conclusions}

We can only hope that most of the panic selling of the 'Southern' sovereign bonds has already taken place and that the crisis is now slowly easing by itself, now that the 'Southern' countries have gone through the necessary adjustment recession. We should note that, currently, only financial institutions that are able to bear some risk still hold these bonds. This is rational since optimally a (risk-weighted) portfolio of (all available) sovereign bonds is held, a behaviour which is often intended to be mimicked by Eurobonds. For just this reason, these holders will not suddenly release the entirely of their bonds to the market, even if difficulties emerge. The current account imbalances will then recede, and the public sector will strengthen. But, admittedly, a perfect 'genuine' Economic and Monetary Union seems impossible in the future, too, due to country-specific interests along a 'North-South' divide [19]. It could, however, be more stable than at present, with a strong banking union that also enforces the fully justified Maastricht vision of hard budget constraints [14,32]. A European Monetary Fund would certainly be another important component of a more stable currency zone [39-41].

This article has identified two principal, but competing, ways to stabilize the Eurozone. With centralized control over fiscal policy and also over some economic policy areas one could introduce a joint liability for government debt to exclude bankruptcies of individual states. In this note we were not able to identify any current willingness and/or democratic legitimacy to proceed in this manner in the short to medium run. Alternatively, one may thus feel forced to leave the decision-making power over public debt to national parliaments. But then it must be possible as a conditio sine qua non that countries become insolvent, and private creditors are held fully responsible-a clear complement to a European Monetary Fund $[39,41]$. However, this is only possible if the financial sector is changed in such a way that government insolvency no longer affects the stability of the banking system. This could be achieved by a banking union. The fundamental problem to be resolved consists of the skeletons that have remained in the cupboards of some countries' banking systems, and which must not be passed on to the community [5].

The emphasis on pushing through a fiscal union as a precondition for debt mutualisation means the debate, at least in Germany, has become a question of 'all or nothing': either deeper political union (i.e. Building Block 2) or deep chaos. This unnecessarily narrows the strategic options for the players and causes the permanent 'North-South' divide described by Belke [5]-which is also mirrored in the Interim Report-severely hampering the realisation of a 'genuine' monetary and economic union.

However, the European Central Bank (ECB) has bought only some time with its Securities Markets Programme (SMP), Longer-Term Refinancing Operations (LTROs) and Outright Market Transactions (OMTs) and it is vital that the fundamental problems are addressed through a concept of a 'genuine' Economic and Monetary Union. A major problem is that many losses are passed on the ECB and redistribution policy is carried out primarily by monetary policy. It would be better if fiscal authorities restructured banks in a targeted fashion. In the medium run, a way must 
be found to protect the ECB and to guarantee a truly financially and politically independent monetary policy. The Interim Report correctly stresses in this respect 'a clear separation between ECB monetary policy and supervisory functions' [4].

The "South" is right in stating that the lack of a budgetary union like that in the US is a design failure. This paper also strongly supports the view that a proper application of the US system would prevent a costly disintegration process of the Eurozone-but maybe for different reasons. In order to assess the "Southern" euro area governments' proposals of debt pooling and compare them with the US benchmark it is necessary to look at the main ingredients of the rules of the game of the US federal system which became clear only after nine defaults by the 1840 s.

Since the US system (unlike the current situation in the Eurozone) prevents central bank loans from being more attractive than market loans, it avoids permanent balance-of-payment imbalances between member states and, in this way, current account deficits which fail to be backed by credible and solid investment projects. In the US, neither the individual, federal state nor the private sector has access to the printing press to finance itself. If the inhabitants of a federal state require financing for their current account deficits, they must offer other states attractive interest rates and provide sufficient collateral to private

\section{References and Notes}

1. European Council. European Council $28 / 29$ June 2012-Conclusions; 2012. Available from: http://www. consilium.europa.eu/uedocs/cms_Data/docs/pressdata /en/ec/131388.pdf (accessed on 9 May 2013).

2. European Parliament. EP resolution of 20 November 2012 with recommendations to the Commission on the report of the Presidents of the European Council, the European Commission, the European Central Bank and the Eurogroup 'Towards a genuine Economic and Monetary Union' (2012/2151(INI)); 2012. Available from: http://www.europarl.europa.eu/ oeil/popups/ficheprocedure.do?reference $=2012 / 2151$ ( INI)\&I=en (accessed on 9 May 2013).

3. European Commission. A blueprint for a deep and genuine economic and monetary union-Launching a European debate. Communication from the Commission. COM(2012) 777 final. Brussels, Belgium: European Commission; 2012.

4. European Council. Towards a genuine Economic and Monetary union. Interim Report. 12 October 2012. Brussels, Belgium: European Council. Available from: http://www.consilium.europa.eu/uedocs/cms_d ata/docs/pressdata/en/ec/132809.pdf (accessed on 9 May 2013).

5. Belke A. Euro Debt: Should the Eurozone's debt be mutualised? Economist Debates. The Economist outside lenders. If they fail, they simply dispense with borrowing and current account imbalances do not spread in the first place.

This contribution is in strong accordance with "Southern view" that the instalment of a US-type budgetary union remains illusionary. The best proof of this is the over-indebted euro area governments crowding, sometimes massively, to reach a substantial increase in the guarantees for excessive national debt contained in the ESM, typically in advance and without conditionality, and more or less hidden through offering the South's "right types" of debt pooling. Experience shows that the latter must suffer from the noncredibility of all variants of rules proposed to prevent moral hazard-which is simply due to a lack of availability of forfeit in terms of gold, foreign exchange reserves or other hard assets involved and to de-activating the interest rate mechanism (by fixing upper bounds for "tolerable" rate movements) which, however, is a central ingredient of the US-system.

\section{Acknowledgements}

This paper heavily relies on [42]. I am grateful for valuable comments to Iain Begg, Christian Deubner, Daniel Gros, René Smits, Guido Traficante and Wolf Schäfer.

online. 11-23 July 2012. Available from: http://www.e conomist.com/debate/days/view/856 to 858/print (accessed on 9 May 2013).

6. Gros D. Banking Union: Ireland vs. Nevada, an illustration of the importance of an integrated banking system. CEPS Commentaries. Brussels, Belgium: Centre for European Policy Studies; 18 October 2012.

7. Mario Draghi backs Wolfgang Schaeuble's 'super commissioner' plan. The Telegraph. 28 October 2007. Available from: http://www.telegraph.co.uk/finance/fi nancialcrisis/9638725/Mario-Draghi-backs-Wolfgang-S chaeubles-super-commissioner-plan.html (accessed on 9 May 2013).

8. Mussler W. Das Phantom der echten Währungsunion. Frankfurter Allgemeine Zeitung, 18 October 2012, p. 9.

9. Belke A, Potrafke N. Does government ideology matter in monetary policy? A panel data Analysis for OECD countries. Journal of International Money and Finance. 2012;31(5),1126-1139.

10. Andersen SA, Eliassen KA. European community lobbying. European Journal of Political Research. 1991;20(2),173-187.

11. Quite consistently, Wolfgang Schäuble argues: "We can only achieve political union if we have a crisis". See: Seeing in Crisis the Last Best Chance to Unite Europe. New York Times, 18 November 2011. Available from: http://www.nytimes.com/2011/11/19/world/euro pe/for-wolfgang-schauble-seeing-opportunity-in-europes 
-crisis.html?pagewanted=all (accessed on 9 May 2013).

12. Belke A, Herz B, Vogel L. Reforms, exchange rates and monetary commitment: A panel analysis for OECD countries. Open Economies Review. 2006;18 (3),S369-S388.

13. Belke $A$, Gros D. Is a unified macroeconomic policy necessarily better for a common currency area? European Journal of Political Economy. 2009;25(1),98101.

14. Gros D. The false promise of a Eurozone budget. CEPS Commentaries. Brussels, Belgium: Centre for European Policy Studies; 7 December 2012.

15. Belke A, Dreger C. Current account imbalances in the euro area: Does catching up explain the development? Review of International Economics. 2012;21(1),6-17.

16. Bundesbank warms to banking union. Financial Times. 19 November 2012. Available from: http:// www.ft.com/intl/cms/s/0/cc55f4d2-3241-11e2-b891-0 0144feabdc0.html\#axzz2ENuSVL6S (accessed on 9 May 2013).

17. Vaubel R. Why the current plans for European Banking Supervision are not well founded. 2012. Available from: http://www.openeuropeberlin.de/Cont ent/Documents/121203_Roland_Vaubel_-_Gastbeitrag .pdf (accessed on 9 May 2013).

18. The de Larosière Group. The High-Level Group on Financial Supervision in the EU Report. Brussels, Belgium: European Commission; 25 February 2009 , p. 43. Available from: http://ec.europa.eu/ internal_market/finances/docs/de_larosiere_report_en .pdf (accessed on 9 May 2013).

19. De Grauwe P. Euro debt: Should the Eurozone's debt be mutualised? Economist Debates. The Economist; 11 to 23 July 2012. Available from: http:// www.economist.com/debate/days/view/856 to 858/pri nt (accessed on 9 May 2013).

20. Belke A. A more effective euro area monetary policy than OMTs-Gold-backed sovereign debt. In: ECB Intervention in the Euro Area Sovereign Debt Markets, Compilation of Notes. Brussels, Belgium: European Parliament; October 2012. Available from: http://www.europarl.europa.eu/committees/en/econ/st udiesdownload. html ?languageDocument $=E N \&$ file $=76$ 695 (accessed on 9 May 2013).

21. International Monetary Fund. World economic outlook-Coping with high debt and sluggish growth. Washington, DC, USA: IMF; October 2012.

22. European Commission. Autumn economic forecast 2012-14: Sailing through rough waters, Brussels, Belgium: European Commission; 7 November 2012.

23. Belke A. Expert-Statement in the Public Hearing on 'Asymmetric Shock or Shock Specific to One Country: On the Need of a Stability Fund under EMU'. Brussels, Belgium: European Parliament, Committee on Economic and Monetary Affairs and Industrial Policy; 2 September 1998. Re-printed in: European Parliament. DB IV Publications, Economic Affairs Series ECON 104,
09/1998. Brussels, Belgium: European Parliament; 1998.

24. Belke A, Gros D. Asymmetric shocks and EMU: Is there a need for a Stability Fund? Intereconomics. 1998;33(6),274-288.

25. This section heavily relies on the debate between Paul de Grauwe and myself on "Euro Debt: Should the Eurozone's Debt Be Mutualised?", Economist Debates, The Economist online, 11-23 July 2012. Needless to say then, the author of this paper feels inclined to support the 'Northern' view more than the 'Southern' view-although he outlines that both approaches are reconcilable, building upon a solution which combines a banking union with fiscal federalism.

26. Gros D, Thygesen N. European monetary integration, 2nd ed. London, UK: Longman; 1998.

27. Belke A, Burghof H-P. Stand-alone ratings for countries-Remedial action in case of market failure. EuroIntelligence. 24 November 2010. Available from: http://www.eurointelligence.com/eurointelligence-new s/archive/single-view/article/stand-alone-ratings-for-co untries-remedial-action-in-case-of-market-failure.html (accessed on 9 May 2013).

28. Delpla J, Weizsäcker J. The Blue Bond Proposal. Breugel.org. 11 May 2011. Available from: http://www.bruegel.org/fileadmin/bruegel_files/Event s/Presentations/2011-03-16_Blue_Bonds_Weizsacker_ Delpla_11th_May_final_Compatibility_Mode_.pdf (accessed on 9 May 2013).

29. German Council of Economic Experts. After the Euro Area Summit: Time to Implement Long-Term Solutions. Wiesbaden, Germany: German Council of Economic Experts; 2012.

30. Padoa-Schioppa Group. Completing the EuroA roadmap towards fiscal union in Europe. Notre Europe. 2012. Available from: http://www.eng.notreeurope.eu/011-3024-Tommaso-Padoa-Schioppa-Group .html (accessed on 9 May 2013).

31. Sinn H-W, Wollmershäuser T. Target loans, current account balances and capital flows: The ECB's rescue facility. International Tax and Public Finance. 2012;19(4),468-508.

32. Gros D. Eurobonds: Wrong solution for legal, political, and economic reasons. VoxEU. 2011. Available from: http://www.voxeu.org/article/eurobon ds-are-wrong-solution (accessed on 9 May 2013).

33. Gros D, Schoenmaker D. A European deposit insurance and resolution fund-An update. CEPS Policy Brief. Brussels, Belgium: Centre for European Policy Studies; 11 September 2012.

34. Gros D, Alcidi C, Giovannini A. Central banks in times of crisis: The FED vs. the ECB, CEPS Policy Briefs. Brussels, Belgium: Centre for European Policy Studies; 11 July 2012.

35. Comments by turbatothomas. The Economist. Available from: https://www.economist.com/users/tur batothomas/comments?page $=1$ (accessed on 9 May 2013).

36. Reply to comment. The Economist. Available from: http://www.economist.com/comment/reply/215 
58392/1521375 (accessed on 9 May 2013).

37. Di Cesare A, Grande G, Manna M, Taboga M. Recent estimates of sovereign risk premia for Euroarea countries. Occasional Papers 128. Rome, Italy: Banca d'Italia; September 2012.

38. Economist Debates: Euro debt: Statements. The Economist. Available from: http://www.economist. com/debate/days/view/856 (accessed on 9 May 2013).

39. Plenum der Ökonomen. Stellungnahme zur Bankenunion. 2012. Available from: http://www.wiso. uni-hamburg.de/lucke (accessed on 9 May 2013).

40. Gros D, Mayer T. How to deal with sovereign default in Europe: Create the European Monetary Fund now! CEPS Policy Brief. Brussels, Belgium:
Centre for European Policy Studies; 17 May 2010.

41. Belke A. Reinforcing economic governance in EMU: The case for a European Monetary Fund. Paper presented at the Panel 'Responses to Potential National Insolvency', Global Economic Symposium (GES), Istanbul, Turkey, 27-29 September 2010.

42. Ansgar B. Towards a Genuine Economic and Monetary Union-Comments on a Roadmap. Briefing paper prepared for presentation at the Committee on Economic and Monetary Affairs of the European Parliament for the quarterly dialogue with the President of the European Central Bank. Brussels, Belgium: European Parliament; December 2012. 